\title{
How Strategy is Adapted and Extended in Social Entrepreneurship
}

\begin{abstract}
We examined three strategy frameworks in the social entrepreneurship context: industrial/organization economics; the resource-based view; and the relational view. Our qualitative study investigated six cases and findings confirmed that all three strategy frameworks were used albeit in sometimes surprising ways compared to commercial enterprises. Social entrepreneurs empowered suppliers and buyers as opposed to reducing these forces, effectuated new ecosystems instead of building competitive advantage in established industries, and saw rivals as co-contributing to solutions.
\end{abstract}

Keywords:

Social Entrepreneurship; strategy; effectuated ecosystems 
Social entrepreneurship (SE) or the simultaneous creation of social and economic value reflects innovations that address social problems plaguing our planet, problems like poverty and social inequality (Martin \& Osberg, 2007; Zahra et al., 2009). Social enterprises have created new institutions (Mair \& Marti, 2009; Dacin et al., 2010), designed products and services with price points 10 to 100 times cheaper than those in developed countries (Prahalad, 2004; Williams et al., 2010), and bridged sectors of society historically at odds with each other (Bruggman \& Prahalad, 2007; Wheeler et al., 2005). However, as we know from strategic entrepreneurship research, strategy is needed to realize the value of any innovation (Hitt et al., 2001). Strategies can be thought of as techniques and methods useful for capturing and extracting value from innovations created and pursued by entrepreneurs (Venkataraman \& Sarasvathy, 2001). Research has examined strategy's effectiveness in developing the value of commercial entrepreneurs' innovations (Hitt et al., 2001) but little is known about how strategy is employed in social entrepreneurship (Dacin et al., 2010).

Scholars recently have called for research that examines strategy specifically in SE (Dacin et al., 2010; Short et al., 2009) and in business and sustainability more broadly (McWilliams \& Siegel., 2011; Hart \& Dowell, 2011). Conceptual articles advocate the resource based view (RBV) of the firm as potentially useful for exploring key bundles of resources that need to be developed by social enterprises (Dacin et al., 2011) and for furthering research on poverty alleviation and other issues for people living on less than \$2US per day (Hart \& Dowell, 2011). We further contend that empirical research is needed to understand how enterprises use strategy when striving for the multiple performance outcomes typical of social enterprises. Multiple performance outcomes are not the norm for conventional commercial business (Russo, 
2010; Hart, 2005) so an examination of the use of strategy frameworks in a multi-outcome context like SE could expand our understanding of these important tools. Moreover, empirical research in the SE context may illuminate implicit assumptions that derive from a single outcome context but which may be relaxed when applied to social entrepreneurship (Dacin et al., 2010; Short et al., 2009). Finally, strategy is acutely relevant for businesses with a vision to uplift disadvantaged groups (Russo, 2010); it offers a systematic way to address the often multi-faceted and ill-defined issues faced by those wishing to create social value (Bruggman and Prahalad, 2007; Hart, 2005; Hart and Dowell, 2011).

Our purpose thus is to explore the use of strategy in the context of social entrepreneurship. Our exploration is empirical and recognizes strategy's potential importance for creating and sustaining value from social innovation, most frequently through social enterprise founding. Given the lack of research on strategy in social entrepreneurship, we implement an inductive study to answer research questions about the role of strategy in social enterprises. Specifically, we review three well-known strategy frameworks including: industrial/ organizational economics (IOE); the resource-based view (RBV); and the relational view of strategy that includes a stakeholder perspective (RV/S). We then analyze six social entrepreneurship cases to address two research questions: 1) What elements of the three strategic frameworks are present in these cases? 2) How do social entrepreneurs adapt or extend any of the elements in these frameworks? Our use of these frameworks has the added benefit of applying established theoretical frameworks to SE, something that has been recommended for theory development in the context of social innovation (Dacin et al., 2010; Short et al., 2009). 


\section{LITERATURE REVIEW}

\section{Social Entrepreneurship}

Much of the literature on SE focuses on defining the concept (Martin \& Osberg, 2007; Mair \& Marti, 2006; Peredo \& McLean, 2006; Zahra et al., 2009) and offers conceptual as opposed to empirical research (Short et al., 2009). Several excellent reviews on the many SE definitions exist(see Dacin et al., 2010; Zahra et al., 2009) but there is no consensual definition of SE in this burgeoning research stream (Dacin et al., 2010; Short et al., 2009; Zahra et al., 2009). In this study, we define SE as processes such as venture founding that involve the innovative use and combination of resources for meeting the needs of marginalized and disadvantaged groups. This definition integrates across many definitions of social entrepreneurship but predominantly reflects a few we see as pivotal: Mair \& Marti, (2006); Martin \& Osberg (2007); and Peredo \& Chrisman (2006).

Another theme in SE research is the description and examination of individual social entrepreneurs' characteristics (Mort et al., 2003; Peredo \& McLean, 2006; Shaw \& Carter, 2007). We read numerous anecdotes of exceptional individuals whose charisma and drive create innovative solutions to social problems that transform society (Alvord et al., 2004; Dacin et al., 2010; Zahra et al., 2009). This focus on individual social entrepreneurs' characteristics mirrors a similar theme in commercial entrepreneurship research but the SE literature relies on individual case studies so that observations remain idiosyncratic (Dacin et al., 2010) and generalizability to the population of social entrepreneurs questionable (Short et al., 2009).

The notion of strategy and its potential role in social entrepreneurship has surfaced in the SE literature but remains largely unexplored (Hart \& Dowell, 2011; Short et al., 2009). The few 
exceptions are predominantly conceptual and are described below. We begin our exploration by reviewing three strategy frameworks.

\section{Strategy Frameworks}

IOE framework. This emerged in the late 1970s and early 1980s through the research of Michael Porter and others. Although substantive limitations have been identified (Johnson, Scholes \& Whittington, 2005), the framework remains a useful lens for understanding strategies firms use to create an enduring advantage relative to rivals. The overarching paradigm of IOE is the structure - conduct - performance (SCP) model wherein: structure refers to the market structure of an industry; conduct refers to the behavior of firms within an industry; and performance is an economy-wide concept encompassing elements of production and efficient allocation of resources (Scherer \& Ross, 1990).

Drawing on the SCP model, Porter (1980) proposed a now widely understood model of five industry forces to be analyzed when deciding on strategy. The five forces represent the structure and power relationships inherent in any industry: suppliers, buyers, barriers to entry, substitutes, and rivalry. Porter (1985) then prescribed generic strategies or positions firms could stake out relative to rival firms in their industry. Again, these strategies have wide currency in strategy texts and business parlance. They include offering products or services at the lowest cost in the industry (low cost); providing products with unique features valued by customers (differentiation); and providing products and services with features tailored to a narrow market segment (focus). Firms that clearly enact positions achieve a competitive advantage that can be seen in profit margins greater than those of rivals (Porter, 1985). Porter elaborates each generic strategy by describing a value chain that would support it. For Porter (1985), value chains 
consist of primary activities including inbound logistics, operations, outbound logistics, marketing and sales, as well as support activities such as human resource management and procurement. Value chains represent collections of physical and technological activities that firms perform to cumulatively add value to products. The concept has been extended beyond the level of the individual firm to apply to whole supply chains and networks.

Very little research applies strategy principles from IOE to social entrepreneurship even though such application would likely help build theory especially regarding how industry conditions affect social enterprise performance (Short et al., 2009). An exception is a study done by Robinson (2006) wherein he explores entry barriers to social entrepreneurship. He extends the conventional notion of entry barriers seen in Porter's five forces model to include social and institutional entry barriers faced by social entrepreneurs when founding ventures. Additionally, some empirical evidence indirectly corroborates the need to consider an IOE perspective within social entrepreneurship in that building value chains was a key activity in the start up of several innovative social enterprise ventures (Corner \& Ho, 2010; Mair \& Marti, 2009).

The broader business and sustainability literature also evidences relatively little research that considers strategy from an IOE perspective, despite some notable exceptions (McWilliams \& Siegel, 2011). One exception is the application of strategy principles from IOE to more environmentally responsible or so-called "green" products and services. For example, Reinhardt (1998) illustrates the notion of differentiation for such products and the potential price premium they can command. Also, Russo (2010, p. 19) cites research from the Natural Marketing Institute showing that LOHAS (consumers pursuing lifestyles of health and sustainability) are "more than twice as likely as the general public to pay $20 \%$ more for goods that they view as 
connected to their lifestyle". In the "green" products and services segment, an extended value chain is implied in the concept of closed loop industrial cycles where, for example, the waste from one manufacturing process is used as inputs for another (McDonough \& Braungart, 2002).

RBV framework. The second strategy framework that emerged was the resource-based view of the firm. The RBV grew from seminal research that conceptualized firms from the resource (Wernerfelt, 1984; Barney, 1986) as opposed to the product-market perspective of IOE. The RBV sees a firm as a bundle of resources that is unique relative to other firms (Barney et al., 2011). Firms that exploit resource bundles that are valuable, rare, inimitable, and have no substitutes will have competitive advantage relative to rivals (Barney et al., 2011). More recently, the RBV includes the notion of dynamic capabilities which extends the framework to competitive landscapes that are continually changing (Teece, Pisano, Shuen 1997; Helfat et al., 2007). In such markets, dynamic capabilities enable firms to enhance and reconfigure existing resource bundles and capabilities in order to sustain competitive advantage (Teece, 2007) or create a series of temporary competitive advantages in the face of an uncertain environment (Eisenhardt \& Martin, 2000). Dynamic capabilities were initially defined as the firm's ability to integrate, build, and reconfigure internal and external competencies to address rapidly changing environments (Teece et al., 1997, p. 516). Dynamic capabilities were recently extended to the entrepreneurial context with the notion of dynamic entrepreneurial capabilities defined as "the capacities that entrepreneurs use to identify, amass, integrate and potentially reconfigure resources as needed in the creation of new ventures" (Corner \& Wu, 2011, p. 2).

Short et al. (2009) point out that the RBV is noticeably absent from theory development in SE. They agree with Dacin et al. (2010) that this absence is unfortunate given the potential of 
the SE context to reveal how unique resource bundles are created when resources are very scarce, a typical situation faced by social entrepreneurs. Moreover, Dacin et al. (2010) see SE research potentially extending the RBV beyond its classic focus on internal resources given social entrepreneurs' need to focus on resources external to an enterprise. Such research provides an excellent opportunity to examine assumptions underlying current strategy frameworks and extend existing entrepreneurship theory (Dacin et al., 2010). For example, the challenges associated with serving these segments, issues like poor infrastructure in economically disadvantaged countries and low literacy rates are likely to force companies to develop unique capabilities in unusual ways (Hart \& Dowell, 2011).

If we move beyond $\mathrm{SE}$ research and consider the broader literature on business and sustainability, the RBV has been applied to firms seeking a competitive advantage derived, at least in part, through a sustainability focus into products and services (Hart, 2005; Hart \& Dowell, 2011). Hart saw potential in a natural resource based view of the firm, recognizing the advantage accruing from the responsible configuration of such resources. This research again focuses predominantly on "green" products and services whose features help preserve the natural environment; rarely does it focus on companies trying to address the needs of marginalized or excluded segments of humanity (Hart \& Dowell, 2011). Bruggman and Prahalad (2007), Hart (2005) and others have labeled these segments the base/bottom of the pyramid and encourage researchers to examine issues of strategy for firms attempting to meet these needs.

$\mathbf{R V} / \mathbf{S}$ framework. The third framework is the relational view of strategy, a view of competitive advantage focused on a dyad or network of firms (Dyer \& Singh, 1998). This relational view changes our perspective on organizations from one of autonomous, self-reliant 
firm actions and outcomes to a relational or collective view of actions and outcomes (Boisot \& McKelvey, 2010). The relational view holds that competitive advantage emanates from idiosyncratic, hard to imitate, inter-firm relationships (Dyer \& Singh, 1998; Yli-Renko et al., 2001). Proponents argue that patterns of interaction and knowledge sharing between firms create specialized knowledge unique to the relationship (Dyer \& Singh, 1998), knowledge that can be applied to create new products, reduce sales costs, and enhance technological distinctiveness (Yli-Renko, et al., 2001). Such knowledge is often tacit, embedded in routine interactions and thus hard to codify and difficult to imitate (Yli-Renko et al., 2001). Also, commercial entrepreneurs build relationships to ensure their organizations' legitimacy (Aldrich \& Fiol, 1994) and to secure resources (Sarasvathy, 2008).

The present study supplements the relational view of strategy with the stakeholder perspective on strategy proposed by Freeman. His classic definition of a stakeholder is any group or individual that "can affect or is affected by the achievement of the organization's objectives" (Freeman, 1984: 46) and includes groups like suppliers, customers, the media, and even activists. Freeman has since clarified the instrumental nature of firms' engagement with stakeholders (Freeman, 1994), which more socially-minded commentators have been inclined to overlook. Organizational strategists are advised to identify stakeholder groups and their key issues when formulating strategy (McVea \& Freeman, 2005), and even to use stakeholders as a source of creative intelligence (Hart \& Sharma, 2004).

The relational view of strategy is indirectly reflected in SE research in two ways. First, some SE research emphasizes the importance of network ties for creating innovative solutions to social problems (Dacin et al., 2010; Peredo \& Chrisman, 2006). Network ties enable people to 
build strong relationships which, over time, allow trust, cooperation, and a sense of collective action to develop. Such ties have proved to be important for social entrepreneurs assisting the ultra poor in Bangladesh (Mair \& Marti, 2009) as well as those addressing the needs of the disadvantaged in inner city locations in the US (Robinson, 2006). Network ties are also implied but not explicitly explored in scholars' descriptions of new ecosystems (Bruggman \& Prahalad, 2007) and networks (Wheeler et al., 2005) that have been created to meet the needs of marginalized or disadvantaged groups. Second, SE research reflects theories of effectuation and bricolage whereby entrepreneurs build processes and structures by combining and recombining available actors into informal and formal networks (Dacin et al., 2010). For example, bricolage was used by a non-government organization in Bangladesh when implementing programs for the ultra-poor (Mair \& Marti, 2009) and effectuation was used by a New Zealand fair trade organization that generated income for impoverished Tibetan refugees (Corner \& Ho, 2010).

In the broader business and sustainability literature, a stakeholder approach to strategy has long been encouraged by scholars advocating sustainable business (Hart \& Sharma, 2004). Similar to the relational view described above, engagement with stakeholders is hypothesized as a means to create new knowledge that can potentially solve the long standing and seemingly intractable problems faced by marginalized or disadvantaged groups (Hart \& Dowell, 2011).

Table 1 summarizes key elements of all three of the well-known strategy frameworks. These frameworks yielded topics (Richards, 2009) that guided coding and interpretation of qualitative evidence as described in the next section. Our findings show social entrepreneurs working with many of the familiar elements of strategy such as competition, buyers, suppliers, as well as taking the strategic actions of building value chains, configuring capabilities, and 
enacting enduring networks of relationships. However, data further suggest that these familiar strategy elements were adapted and/or extended to meet the challenges presented by the SE context where entrepreneurs were trying to find solutions for multi-faceted, seemingly intractable problems. Using an approach by Farjoun (2010) outlined in the implications section (below), we came to see social entrepreneurs' use of strategy elements as complementary, not contradictory to, the use of these elements by commercial enterprises.

Insert Table 1 About Here

\section{RESEARCH METHODS}

We pursued our research inductively using six cases of social entrepreneurship. An inductive approach is appropriate given the lack of research on the topic of strategy in social entrepreneurship (Yin, 2003) and has been associated with ground-breaking insights in management research (Short et al., 2009). The use of an inductive approach does limit generalizability; it is thus best to view the findings as exploratory and suggestive of strategy

elements that may be present in a broader population of social enterprises. The use of multiple cases, however, allowed a replication logic whereby each case was used to test emerging theoretical insights (Yin, 2003). Such a comparative analysis of cases provides an understanding of complex phenomena (Alvord et al., 2004).

\section{Cases and Data Collection}

Data that allow generalizability to theory can be exorbitantly expensive to collect (Alvord et al., 2004) and pose perhaps the greatest challenge facing SE researchers (Short et al., 2009). This is because SE occurs across multiple national contexts, sizes of organizations, and varied 
product/ service offerings. Short et al. (2009) advocate creative solutions when sourcing SE data and we adopt one such solution -- the use of existing accounts of SE (Alvord et al., 2004).

We constructed six case studies from existing accounts that centered on enterprises founded to address issues for marginalized or disadvantaged groups. We initially selected 6 companies reflected in teaching cases submitted to the oikos Global Case Writing Competition in the social entrepreneurship category supported by Ashoka. The six teaching cases had won first, second or third place in this competition in 2009 and 2010. However, one of the companies described in these teaching cases was excluded because it focused exclusively on creating environmental rather than social benefits and was thus inconsistent with the definition of social entrepreneurship guiding this research. The company was replaced with one that had also been described in a teaching case submitted to the oikos competition but had not placed. The teaching cases describing these six companies were available as published teaching cases and served as our first source of data for each case. The cases collectively covered a range of different contexts (small and medium size enterprises, from different countries, offering varied products/services), thereby enabling identification of patterns across diverse situations.

Our second source of data was information from company websites and other Internet locations. We recognized that this information, drawn together by the authors subsequent to the time each case was constructed does, on occasion, deal with issues not contemporaneous with the cases, and an effort was made not to confuse the timeframes or contaminate the accumulated data with post hoc rationalizations. A third source of data for the cases was the teaching notes prepared for the teaching cases. We approached the authors and co-authors of the cases, and 
asked for permission to review the teaching notes. All authors contacted made this information available. The cases and their orientation are summarized in Table 2 below.

Insert Table 2 Below

\section{Data Analysis}

Data were analyzed using familiar approaches for qualitative, inductive data analysis (Miles \& Huberman, 1984; Richards, 2009; Yin, 2003). We coded data by first identifying passages in textual material that represented a strategy insight and assigning it to one of the three strategy frameworks. This is essentially topic coding or the labeling of text according to its subject (Richards, 2009). A second step involved coding how each passage reflected an element within the strategy framework, such as buyers, one of the five forces within the IOE framework. This step also involved coding if and how the social enterprises used this element differently from commercial enterprises. Importantly, strategy elements were not always used differently. This second coding step involved more interpretation on the part of researchers, a common progression in coding of qualitative data (Miles \& Huberman, 1984). Data sourced from teaching notes were used predominantly for interpretation. Coding was done by the two authors separately and reviewed collectively. Coding discrepancies were resolved through discussion.

Within-case analysis was then conducted by answering the research questions for each case. These answers were the basis for developing patterns that were then tested by replication logic during the cross-case analysis. These patterns were kept "close to the data" in that we noted and described patterns from the points of view expressed within each case, identifying how the pattern played out in the specific case. When commonalities in patterns began to emerge as 
we moved from case to case, we took note of them but did not further refine emerging patterns until we finished our analysis of the separate cases.

Cross-case analysis produced patterns from within all three of the strategy frameworks. We began with patterns noticed during within case analysis but additional patterns emerged as we progressed through cross-case analysis. We generally compared two or three cases at a time before considering whether or not a pattern generalized across all cases. The approach kept us strongly connected to the data so that we did not prematurely elevate the level of abstraction. As patterns emerged, we continually cycled back to the data to ensure that any identified patterns were well grounded in evidence.

\section{STRATEGY PATTERNS IN STRATEGIC ENTREPRENEURSHIP}

Analysis of qualitative evidence addressed the two research questions. Table 3 summarizes our findings regarding the first research question: What elements of the three strategy frameworks were present in the six cases? The second column shows the number of strategy insights consistent with each strategy framework across the cases. The third column reports selected examples of strategy being enacted consistent with each of the strategy frameworks. Column two shows that all three strategy frameworks were present in all six cases, with a preponderance of insights aligning with the IOE framework. In several instances, a particular strategy insight from a case straddled two of the frameworks such as a relationship (RV/S) being used to build a capability needed by the new venture (RBV). These instances were coded as representing both frameworks since our purpose was to interpret the data, not to make a strict count of occurrences. In sum, Table 3 indicates that strategy is important for social entrepreneurship as conjectured by SE researchers in conceptual research but rarely examined 
empirically (Dacin et al., 2010; Short et al., 2009). These findings are also consistent with what is predicted by conceptual models in the broader business and sustainability literature (Hart, 2005; Hart \& Dowell, 2011; Russo, 2010). More specifically, findings indicate elements of all three strategy frameworks were used by social entrepreneurs. All three frameworks thus have the potential to enrich our understanding of the link between strategy and social entrepreneurship. This finding was somewhat unexpected given that the IOE and RV/S frameworks are mentioned far less than the RBV in the context of social entrepreneurship.

Table 4 presents patterns that answer research question two: How do social entrepreneurs adapt or extend any elements in these frameworks? Adaptations/ extensions are reported in the second column and examples from the data are given in the third column. Adaptation involves modifying a strategy element while an extension is expanding the range of a strategy element.

Insert Tables 3 and 4 About Here

\section{IOE Findings}

We identified four patterns that reflect adaptations and/or extensions of strategy elements within the IOE framework (see Table 4). These include extreme low cost, five forces adapted, multiple value point products, and unconventional value chains. These adaptations and/or extensions indicated that social entrepreneurs drew on strategy elements from the IOE framework but implemented them differently from their commercial counterparts.

Extreme low cost. Enterprises drove costs as close to zero as possible to enable price points that the poorest of customers could afford. Extreme low cost is both an extension and adaptation of Porter's generic low cost strategy. It is an extension of Porter's strategy because 
the cost minimization needed to make products affordable was an order of magnitude lower than commercial sector costs. For example, Wello was pushed to design a manufacturing system that would fit into a railway container and could be shipped to where the customer was, in order to minimize any transport costs for individual waterwheels being passed onto the customer, the classic base of the pyramid person living on less than \$US2 per day. Similarly, the inventor of the technology behind WHI thought he had an extreme low cost way to irradiate pathogens from water but costs were not low enough when the company tried to sell irradiators as a product (4 cents per ton) and WHI declared bankruptcy. The company reinvented itself through a new business model with even lower costs ( 2 cents per ton) wherein water cleaning systems were financed for villages and water cleaning offered as a service. The Wello water wheel case further illustrates the extreme low cost pattern even when the product was thought of as a business opportunity for other entrepreneurs. Wello's founder estimated that the cost of water wheel "franchise" had to be kept under \$US47, the amount of the average micro-loan, in order to ensure its affordability in poor areas of Africa. As such, our findings lend credence to Prahalad's (2004) prediction that price points for companies trying to serve base of the pyramid customers would reflect a 10 to 200 times cost advantage if compared with products/ services targeted to commercial customers in developed markets. Future research could explore how social enterprises may disrupt established industries with such ultra low cost products given that these companies are increasingly infiltrating for-profit competitive space (Short et al., 2009).

The extreme low cost pattern was also an adaptation of Porter's low cost strategy because social enterprises judged low costs using a metric different from that used by Porter. Porter's metric is competitors' costs; a focal firm strives to go below these while maintaining an average 
price to achieve a low cost strategy (Porter, 1985). Our data showed social entrepreneurs using customers' income levels and what a challenging metric it proved to be. Social entrepreneurs had to offer products/ services at a price point that enabled consumption by the poorest of customers (Anderson \& Billou, 2007), like in the case of Wello's water wheel. Furthermore, our evidence suggests that using scale economies to enable overall low cost was not possible. Products/ services had to be designed to meet local conditions which WHI, for example, found could vary even within a given country like India. This inability to minimize cost through large scale echoes findings regarding problems with employing a standard franchise model when using micro-franchising as a distribution mechanism in base of the pyramid markets (Kistruck et al., 2011). A standard model does not work given local variations in culture and customs.

Five forces Adapted. We identified a pattern of social entrepreneurs adapting Porter's five forces (1980) when founding businesses to address social issues. These modifications, however, were not simply the "opposite" of the ideal five forces for commercial companies as might be assumed when social, not economic value is the primary focus. Our findings reveal social entrepreneurs adapted Porter's forces in complex and nuanced ways, reflecting that economic outcomes still mattered while trying to create social value and that trade-offs between economic and social outcomes can be complicated (Russo, 2010). Social entrepreneurs did construct entry barriers in an attempt to make it difficult for competitors to imitate their products or services. For example, PlayPumps of Africa and Trade Aid both used trademarks. PlayPumps faced a lot of competition from other social entrepreneurs trying to address the issue of potable water in Africa and wished to trademark its unique design and business model for addressing this issue to prevent others from imitating it. Trade Aid went through the rigorous 
process of obtaining certification from Fair Trade International in order to distinguish its agricultural products (coffee, tea, spices) from companies offering products that met much less rigorous fair trade standards. This was a surprising adaptation of entry barriers because these barriers were created for competitive reasons when the SE literature suggests that social enterprises develop and use resources for collaborative, not competitive purposes (Dacin et al., 2010). However, this pattern indicates that social enterprises do develop and deploy resources for competitive purposes, consistent with economic objectives. Attention to economic objectives, at least minimal ones, ensures survival of companies pursuing social value creation (Russo, 2010). PlayPumps was concerned with growth, Trade Aid needed to earn enough income to survive, and WHI wanted to make a profit from its proprietary technology while simultaneously providing pure water for millions that had never had it.

Considering two more of Porter's five forces, our findings suggest social enterprises empowered suppliers and buyers while Porter's classic model advocates minimizing these forces. This is a clear adaptation of Porter's model. The Trade Aid case illustrates social entrepreneurs empowering suppliers, consistent with usual practice in the fair trade movement. This company increased the income economically disadvantaged suppliers earned from handcrafted and agricultural products, and trained suppliers to take advantage of additional entrepreneurial opportunities that arose. PlayPumps empowered buyers to improve their health but also enabled children to attend school and women to earn income since the amount of time spent hauling water was much reduced. Similarly, WHI empowered impoverished people in multiple regions to become entrepreneurs by funding their purchase of microfranchises of WHI's water systems. 
Finally, social entrepreneurs thought strategically about potential competition, the force known as rivalry in Porter's five forces model. Our findings show social entrepreneurs adapting this standard notion in that they were relatively sanguine about prospective rivals and saw "room for competitors". Specifically, the entrepreneurs recognized the need to have other rivals moving into the space they were serving because the issues being addressed were large, important, and often intractable such that one company could not address the issue singlehandedly. Kapai's founders recognized the need to have other competitors helping advance its social mission as did WHI's managers who saw the enterprise playing a leadership role in a market large enough for numerous others. We see this as an adaptation of Porter's notion of rivalry, although Porter does allow that some industries have a polite understanding among competitors that leads to low rivalry. It is an adaptation because of the differences in motivations; social entrepreneurs are trying to address social issues while entrepreneurs and managers in the commercial context that Porter was describing are motivated by economic returns. Such returns are enhanced for individual firms through competitive tactics like price competition and advertising (Porter, 1980). The social entrepreneurs did not dismiss economic outcomes but they appreciated that authentic rivals could help solve the social problem they were addressing.

Products/ services with multiple value points. Our data showed social entrepreneurs thinking strategically about products/ services as recommended by the IOE framework. Specifically, we saw a pattern of social enterprises creating products with multiple value points. While product performance and quality is an important consideration within IOE (Scherer \& Ross 1990), current findings suggest an extension of this theme in that a singular product had to 
be multifunctional and appeal to more than one kind of customer. These multiple value points were necessary because poor customers were acutely sensitive to price - and the more value that product models/ designs appeared to have the more likely these customers were to spend their meager income on them. Also, multiple value points were needed to address the social problems that were multi-faceted. For example, Wello's water wheel was designed to transport water for a family in the first instance. However, to create additional value, the water wheel had to transport other necessities (such as rice) effectively. Furthermore, the water wheel had to function as a microfranchise opportunity whereby potential entrepreneurs could simultaneously generate personal income and assure wide "distribution" of water in the company's drive solve the overarching water issue. WHI faced similar challenges trying to supply disinfected water to poor villagers. WHI provided a high-technology solution with a water irradiating device but the enterprise still needed to create additional value points for the product including business models for different geographical regions, a service model that replaced the product approach, and an attractive business opportunity based on the device so that impoverished entrepreneurs would invest in it to ensure maximum distribution of purified water. This pattern corroborates the anecdote of the Chinese appliance manufacturer who discovered its poorer, rural customers were using washing machines to clean vegetables as well as clothes (Anderson \& Billou, 2007). The company modified its machines to cope better with vegetable washing and developed another model that made cheese from goat's milk. Collectively, these social enterprises were solving multifaceted problems and thus needed multi-functional product "solutions".

Unconventional value chains. Cases reflected a fourth pattern pertinent to the IOE framework - unconventional value chains. Our findings verified the value chain as an important 
consideration for social entrepreneurs; much time and effort went into creating the value adding activities and infrastructure required to offer a product or service. This need to create infrastructure is common in SE, especially for those enterprises operating in less developed countries (Mair \& Marti, 2009). However, the pattern constitutes an adaptation of the value chain notion from IOE, as value chains were shaped largely by the need to solve a social problem such as delivery of pathogen-free water by WHI or an income for Tibetan refugees by Trade Aid. The drivers of value chain formation in SE thus were different from drivers in the traditional IOE view where value chains are shaped by the strategy, low cost or differentiation, a company has for making profit (Porter, 1985). This value chain adaptation was evidenced in four of the six cases. For instance, WHI ultimately exhibited a collection of service activities as opposed to product activities because a service model better delivered pathogen free water to rural Indian villages. Moreover, WHI had to build disparate value chains in different locations tailored to local conditions: Different activities were needed to solve the water problem in separate locations. The ReUse People's value chain was unconventional in that the business spawned a new, albeit niche industry trying to create social as well as environmental value around building deconstruction. Its value chain thus reflects a mix of activities to solve both social and environmental problems. Wello invented a novel manufacturing process driven by the particular challenge of providing water to African villages. This pattern verifies findings from Mair and Marti's (2009) single case study where the challenge of addressing the needs of the ultra poor in Bangladesh shaped the infrastructure an NGO had to create to solve the problem. Collectively, these findings suggest that future research examining the drivers of value chain activities may be 
fruitful. For example, researchers could explore the systematic differences in value chains in commercial versus social enterprises.

\section{RBV Findings}

We surfaced four patterns that constitute adaptations/ extensions of strategy elements within this framework as summarized in Table 4. Patterns include: unique funding abilities, emphasis on external resources, complex structuring and governance capabilities, and capabilities reflecting entrepreneurs' life experiences and paradigm shifting aspirations. Together, patterns suggest dynamic entrepreneurial capabilities in that social entrepreneurs developed a capacity to amass, integrate, and reconfigure the critical resources necessary to establish a new enterprise (Corner \& $\mathrm{Wu}, 2011)$. Moreover, the patterns show how knowledge of the RBV can be extended through research in SE, providing empirical evidence that has been called for but not yet provided (Dacin et al., 2010; Short et al., 2009).

Unique funding capabilities. Social enterprises developed funding capabilities that were unique when compared to those of commercial business (see Table 2). These funding capabilities are a particularly good illustration of dynamic entrepreneurial capabilities in that social entrepreneurs developed a capacity to amass the critical resource of funding and reconfigure funding streams when necessary (Corner $\& \mathrm{Wu}, 2011)$. Such a capability is vital to successful enterprise founding because there is often a lack of capital markets for developing social enterprises (Robinson, 2006; Peredo \& Chrisman 2006).

We see this capability as an extension of the RBV because social entrepreneurs amassed funds from different sources using disparate mechanisms in comparison to commercial entrepreneurs who typically fund through debt and owners' equity. Funding mechanisms ranged 
from WHI constructing a complex web of private sector donations for its water purifying systems to PlayPumps securing smaller donations via the Internet and other funding through selling advertising space on its equipment. Findings thus corroborated researchers' conjectures that conventional funding is often unavailable for social entrepreneurs (Robinson, 2006) so founders must be creative about venture finance (Short et al., 2009). We further this research by showing specific mechanisms that were used. The amount of finance these social enterprises were able to raise as donations is a testament to what Russo (2010) calls the authenticity of the companies' mission - donors believed the company was doing what it said it was doing. While Russo (2010) focuses on the importance of authenticity to gain and keep customers, current findings show authenticity's importance for raising funds for social enterprises.

Emphasis on external resources. This pattern involved social entrepreneurs drawing substantively on external resources when amassing and configuring resources for nascent enterprises. This finding was surprising given the RBV's strong focus on resources internal to the firm (Barney, 1986; Barney et al., 2011). We view this reliance on external resources as an adaptation of the RBV. For example, Wello secured essential product design skills for its water wheel via donations from of skill and time from people outside the enterprise. Trade Aid relied heavily on a system of volunteer labor to staff warehouse and retail outlets. This finding requires further exploration. In particular, we need to understand what it is about the SE context that might shift the focus of resources to include external as well as internal resources (Dacin et al., 2010; Short et al., 2009). Resource dependence theory may help illuminate this emphasis on external resources in the SE context (Short et al., 2010). 
Complex structuring and governance capabilities. These social enterprises exhibited a pattern of structuring and governance capabilities that were very complex relative to firm size. For example, three of the organizations had a mix of commercial and non-profit units within the overall company structure. Complex structures are very unusual for commercial enterprises of similar size (i.e., small and medium sized organizations that are known for simple, functional structures (Johnson et al., 2005)). We viewed this pattern as an extension of the notion of capability development central to the RBV given that complex structure and governance mechanisms are vehicles for building multi-faceted capabilities (Madhok, 1996). We contend that the complex structures and governance mechanisms seen in the cases were implemented to match the complexity of the problems and environments social entrepreneurs were confronted with (Boisot \& McKelvey, 2010). Furthermore, complex structures and governance helped social entrepreneurs secure funding and other essential resources (Madhok, 1996). For instance, WHI included as board members representatives from commercial companies that had made substantial donations to WHI. Our findings, along with other evidence (Mair \& Marti, 2009); suggest SE as a fruitful context for further exploration of how the need to amass and configure resources drives structure and governance mechanisms.

Capabilities reflect entrepreneurs' life experiences. A final pattern within the RBV framework is capabilities reflecting entrepreneurs' life experiences and paradigm shifting aspirations. We see it as an extension of capability development for conventional companies. The entrepreneurship literature acknowledges that company capabilities can derive from founders' professional experience and knowledge (Shane, 2000; Sarasvathy, 2008). The companies we studied clearly had evolved capabilities that were influenced by founders; 
however these capabilities emerged not just from professional experience and knowledge but also from founders' life and humanitarian experiences. For example, the founder of Trade Aid helped settle Tibetan refugees in India in the late 1960s and returned to New Zealand with a commitment to continue helping them. The social entrepreneurship literature has considered how entrepreneurs' life experiences affect their recognition and development of opportunities (Corner \& Ho, 2010) but has not yet explored how these personal attributes of founders get specifically reflected in their enterprises' capabilities. Given this pattern, future research might explore the integration of personal identity theory and resource configuration in entrepreneurial enterprises and compare how this is different in social versus commercial enterprises.

\section{RV/S Findings}

Evidence revealed two patterns pertinent to this framework as seen in Table 4. These include building ecosystems via relationships and creating a network of entrepreneurs. Overall, we saw substantial evidence that social entrepreneurs were implementing ideas from the relational view of strategy which illustrates the robustness of this framework.

Built ecosystems via relationships. The social enterprises built ecosystems or systems of complex and intricate relationships in the struggle to amass resources and manifest enterprises that could provide solutions to social problems. Specifically, partnerships were built across multiple sectors of society, with these social enterprises working with governments, foundations, NGOs, and even traditional village elders in rural India. The enterprises worked with local groups and organizations to gain knowledge and build trust, similar to Shaw and Carter's (2007) social entrepreneurs. Also, enterprises used relationships to assure prospective clients of authenticity in their attempts to resolve problems congruent with the local context. 
We saw this pattern as an extension of the relationship view of strategy because the complex webs of relationships being enacted by social entrepreneurs were a step beyond the dyads and networks typically described in the commercial setting - constituting what SE researchers call ecosystems (Bruggman \& Prahalad, 2007; Martin \& Osberg, 2007). Ecosystems are webs of relationships across many different kinds of groups and organizations, potentially including large businesses and NGOs (Bruggman \& Prahalad, 2007) as well as small and medium sized enterprises, community groups, cooperatives, and even family groups (Wheeler et al., 2005). We find the term ecosystem descriptive of these cases because it conveys a sense of emergence of a new system of relationships where the term network commonly conveys an already established set of relationships.

Creating networks of entrepreneurs / microfranchising. The second pattern we identified within the RV/S strategy framework was that of establishing a network of entrepreneurs. For example, WHI and Trade Aid created cadres of entrepreneurs as distribution systems for their products. Wello had a similar "business in a barrel strategy" - an idea to sell water wheels to economically disadvantaged people who could use them to earn an income by delivering water, rice, and other consumables to fellow villagers. This strategy would distribute water wheels into African villages as well as create self-supporting entrepreneurs out of previously economically marginalized people. These examples are analogous to the creation of franchises or micro-franchises which researchers identify as a good strategy for building distribution systems in less developed countries where such infrastructure typically does not exist (Anderson \& Billou, 2007; Kistruck et al., 2011). However, building and sustaining relationships with franchisees is essential to ensure their success (Mair \& Marti, 2009; Kistruck 
et al., 2011). Such franchisees are often uneducated, untrained and risk-averse, and expect their relationship with the franchisor to fill these gaps (Kistruck et al., 2011).

We saw this pattern as extending a relationship view of strategy to the context of less developed economies where social entrepreneurs typically are working. These nations often reflect low literacy rates, underdeveloped formal institutions, rudimentary financial markets, and little infrastructure (Kistruck et al., 2011). We see the potential for the RV/S to further our understanding of entrepreneurship in these contexts. For instance, this strategy framework could be used to further our knowledge of the microfranchise movement. In particular, it could be used to identify which characteristics of the franchisor/ franchisee relationship help ensure success in less developed countries as well as the SE context. Such research is important given Kistruck et al.'s (2011) conclusion that the franchise model that we know and understand in Western, developed countries does not translate well into less developed economies.

The above two patterns indicate what was created - outcomes of a relational view of strategy. It is also useful to consider how relationships were cultivated. Social entrepreneurs often began with existing personal contacts, similar to Shaw and Carter (2007). As such, our findings endorse the process notions of bricolage and effectuation from the entrepreneurship literature, concepts describing entrepreneurs as utilizing relationships and other resources already at hand (Corner \& Wu, 2011; Sarasvathy, 2008). Effectuation also implies that prospective customers work with the entrepreneur to co-create and design products to reflect customer preferences (Sarasvathy 2008), an idea that has also come to the fore in research about missiondriven companies (Russo, 2010). Our cases showed local groups working with founders to ensure that products and services were tailored to the needs of local customers. Bricolage (Mair 
\& Marti, 2009) and effectuation (Corner \& Ho, 2010) have surfaced in the SE literature but current findings suggest that integrating the RV/S framework with these process notions may further our understanding of social enterprise founding.

\section{IMPLICATIONS AND CONCLUSION}

The above findings provided initial empirical evidence that strategy elements from three well known frameworks appeared in social enterprises and were adapted or extended relative to their intended use in commercial enterprises. Surfaced patterns showed social entrepreneurs building unconventional value chains, driving costs to near zero, designing products with multiple value points, creating structures and governance systems with great complexity relative to small enterprise size, and building ecosystems of relationships across sectors and geographical locations. Although not all elements from the strategy frameworks surfaced in identified patterns, we contend there is sufficient evidence to encourage more in-depth and broader scale research on this topic. Moreover, findings showed social entrepreneurs adapted and extended strategy elements thereby showing the potential flexibility of strategy elements for capturing and extracting value from social innovations such as PlayPump's merry-go-round and WHI's water irradiator. These adaptations/ extensions imply strategy as link between social and commercial companies that could be used to uncover complementarities between these separate but related organizational forms (Zahra \& Wright, 2011). Unfortunately, strategy in SE is under-researched (Dacin et al., 2010; Hart \& Dowell, 2010; Russo, 2010) such that theoretical and practical knowledge that could contribute to solving social problems is limited to date. We thus discuss two implications for the wider literature that may help spark research and extend knowledge.

First, the strategy adaptations/ extensions revealed by findings highlight the novelty of the social entrepreneurship context for strategy. We suggest that further exploration of this 
context may offer unique insights into strategy theory and practice. As mentioned, the social entrepreneurship context is one in which entrepreneurs often face low literacy and education rates, extreme poverty, skilled labor shortages, and limited transportation facilities (Dacin et al., 2010) as well as a lack of social order, local knowledge, and active financial markets (Robinson, 2006). It is different from the typical strategy research context that reflects large, established firms (Corner \& Wu, 2011; Helfat et al., 2007) pursuing private wealth generation (Mair \& Marti, 2006) in well developed economies (Kistruck et al., 2011). We suggest that further examining strategy in this context may reveal limitations and assumptions underlying current theory. For example, the complex structures created by the small and medium sized social enterprises hint at a richness in the relationship between strategy and structure that is missing in our current understanding of this link. Furthermore, empirical research examining the role of market structure and positioning in social enterprises versus commercial enterprises seems justified given our findings regarding buyers, suppliers, competition, and "extreme low cost". What relevance does market structure have for social entrepreneurs? Similarly, what does the notion of extreme low cost reveal about Porter's low cost strategy - is the assumption of a single bottom line an inherent limitation in strategy frameworks? Are rivals, in part at least, an answer to individual social enterprises achieving the scale needed to tackle widespread social problems, the scale that an individual enterprise seems unable to achieve on its own? Hart and Dowell (2011) call for breakthrough strategies in the area of business sustainability, strategies that will solve problems, not just reduce impact. We suggest that further examination of strategy elements from all three frameworks may reveal possible breakthrough strategies for social enterprises and provide insights regarding how these could be applied to commercial companies. 
A second related implication of our findings is that the accepted understanding of strategy, like other concepts in management research (Farjoun, 2010), may not fully capture its richness and potency. Farjoun (2010) points out that what seems contradictory may be reframed as complementary if a researcher decouples mechanisms from outcomes. He does not discuss strategy but he does discuss concepts like routines and institutions and argues that decoupling mechanisms from outcomes for these concepts is a way to tap into their richness and complexity. Our findings at first glance may appear to suggest contradictions in the way strategy concepts were applied in the social versus commercial enterprise context. For example, reported patterns revealed that social enterprises empowered buyers and suppliers while the accepted understanding of Porter's five forces model is these forces should be minimized or threats arising from them eliminated. However, an interpretation of findings from Farjoun's perspective is that the context of social entrepreneurship enabled us to decouple outcomes such as profit and private wealth generation from the "mechanism", Porter's model, such that a potential richness to the concepts of buyers and suppliers begins to unfold. Once decoupled from outcomes, the mechanisms of buyers and suppliers may not have to function to maximize profit for the focal firm but may be free to function in a complementary way in the SE context. Stated differently, a firm may have multiple strategic options regarding buyers if it is not tied to private wealth generation. Interpreted in this fashion, our findings do not diminish the relevance or power of strategy frameworks but enhance them and advocate for a new context within which to apply them. Farjoun (2010) suggests that such applications can lead to breakthrough innovations and we agree based on our examination of the six cases in this study. 
Like all research, our study has limitations to be considered when interpreting findings. The first potential limitation is the use of existing accounts to construct cases. Although these cases have benefits such as generalizability (to theory) beyond a single national context and single product/ service (Alvord et al., 2004), one could argue that they do not yield as thick a description as would be produced by first-hand interview data. We ameliorated this potential limitation by augmenting data on the focal companies as much as possible. Nevertheless, we explicitly state this issue as a caution to readers and encourage them to interpret findings accordingly. Another limitation to consider is that three of the cases included were about providing potable water to impoverished regions. In part, external validity is enhanced by the widespread nature of this social problem globally and the extent to which it is a core issue being tackled currently by social entrepreneurs. External validity also is enhanced by the fact that these cases placed in the oikos competition. Nevertheless, a sample of cases across a more diverse set of social problems could have expanded the generalizability of findings to theory even further.

In conclusion, our findings take an initial step towards empirically exploring strategy in social entrepreneurship using multiple theoretical frameworks. Importantly, we conclude that strategy is a crucial management capability for social enterprise and suggest that further exploration of strategy in the SE context has the potential to both illuminate solutions to social problems and extend strategy theory and practice. 


\section{REFERENCES}

Aldrich, H. \& Fiol, M. 1994. Fools rush in? The institutional context of industry creation. Academy of Management Review, 19: 645-666.

Alvord, S., Brown, L., \& Letts, C. 2004. Social entrepreneurship and societal transformation. Journal of Applied Behavioral Science, 40: 260-282.

Anderson, J. \& Billou, N. 2007. Serving the world's poor: innovation at the base of the economic pyramid. Journal of Business Strategy, 28: 14-21.

Barney, J.B. 1986. Organization culture: Can it be a source of sustained competitive advantage? Academy of Management Review, 11: 656-665.

Barney, J.B., Ketchen, D.J., \& Wright, M. 2011. The future of resource-based theory: Revitalization or decline? Journal of Management, DOI:10.1177/0149206310391805.

Boisot, M. \& McKelvey, B. 2010. Integrating modernist and postmodernist perspectives on organizations: A complexity science bridge. Academy of Management Review, 35(3): 415-433.

Bruggmann, J. \& Prahalad, C.K. 2007. Cocreating business' new social compact. Harvard Business Review, February: 80-90.

Corbett, C. \& Powell, W. 2009. The ReUse People: Turning scrap into sales. Case Studies in Social Entrepreneurship and Sustainability: The oikos Collection Vol 2: 346-369.

Corner, P. \& Ho, M. 2010. How opportunities develop in social entrepreneurship. Entrepreneurship, Theory and Practice, 34: 635-659.

Corner, P. \& Wu, S. 2011. Dynamic capability emergence in the venture creation process. International Small Business Journal, DOI: 10.1177/0266242611431092.

Dacin, P. Dacin, T. \& Matear, M. 2010. Social entrepreneurship: Why we don't need a new theory and how we move forward from here. Academy of Management Perspectives, August: 37-57.

Dyer, J. \& Singh, H. 1998. The relational view: Cooperative strategy and sources of interorganizational competitive advantage. Academy of Management Review, 23: 660-679.

Eisenhardt, K. \& Martin, J. 2000. Dynamic capabilities: What are they? Strategic Management Journal, 21: $1105-1121$.

Faheem, H. \& Purkayastha, D. 2010. WaterHealth International: Providing safe drinking water to the bottom of the pyramid consumers. Case studies in social entrepreneurship and sustainability: The oikos collection Vol 2. St.Gallen: Oikos Foundation for Economy and Ecology: 256-290. 
Farjoun, M . 2010. Beyond dualism: Stability and change as a duality. Academy of Management Review, 35: 202-225.

Freeman, R.E. 1984. Strategic Management: A Stakeholder Approach. Boston: Pitman.

Freeman, R. E. 1994. The politics of stakeholder theory: Some future directions. Business Ethics Quarterly, 4: 409-421.

Gordon, M. 2010. So you want to be a social entrepreneur: Starting out, scaling up and staying committed. Case studies in social entrepreneurship and sustainability: The oikos collection Vol 2. St.Gallen: Oikos Foundation for Economy and Ecology: 31-42.

Hart, S. 2005. Capitalism at the Crossroads. Upper Saddle River, NJ: Wharton School Publishing. Hart ,S. \& Sharma, S. 2004. Engaging fringe stakeholders for competitive imagination. Academy of Management Executive, 18: 7-18.

Hart, S. \& Dowell, G. 2011. A natural resource-based view of the firm: Fifteen years after. Journal of Management, 37: 1464-1479.

Helfat, C.E., Finkelstein, S., Mitchell, W., Peteraf, M., Singh, H., Teece, D. \& Winter, S. 2007. Dynamic Capabilities: Understanding Strategic Change in Organizations. London: Blackwell.

Hitt, M., Ireland, R.D., Camp, S.M., Sexton, D. 2001. Guest editors' introduction to the special issue strategic entrepreneurship: Entrepreneurial strategies for wealth creation. Strategic Management Journal, 22: 479-491.

Ho, M. \& Corner, P. 2010. Trade Aid: Building just and sustainable communities through social entrepreneurship. In I Hunter and K Morris (eds.) Innovation and Entrepreneurship: New Zealand Case Series 2. Melbourne: McGraw-Hill: 34-52.

Johnson, G., Scholes, K. \& Whittington, R. 2005. Exploring Corporate Strategy. London: Prentice Hall. Kistruck, G., Webb, J., Sutter, C., \& Ireland, R.D. 2011. Microfranchising in base-of-the-pyramid markets: Institutional challenges and adaptations to the franchise model. Entrepreneurship, Theory and Practice, DOI:10.1111/j.1540-6520.2011.00446.x.

Madhok, A. 1996. The organization of economic activity: Transaction costs, firm capabilities, and the nature of governance. Organization Science, 7: 577-590.

Mair, J. \& Marti, I. 2006. Social entrepreneurship research: A source of explanation, prediction, and delight. Journal of World Business, 41, 36-44.

Mair, J. \& Marti, I. 2009. Entrepreneurship in and around institutional voids: A case study from Bangledesh. Journal of Business Venturing, 24: 419-435. 
Martin, R. \& Osberg, S. 2007. Social entrepreneurship: The case for definition. Stanford Social Innovation Review, Spring: 28-39.

McDonough, W. \& Braungart, M. 2002. Cradle to Cradle: Remaking the Way we make Things. New York: North Point Press.

McVea, J. \& Freeman, R. E. 2005. A names-and-faces approach to stakeholder management: How focusing on stakeholders as individuals can bring ethics and entrepreneurial strategy together. Journal of Management Inquiry, 14: 57-69.

McWilliams, A. \& Siegel, D. 2011. Creating and capturing value: Strategic corporate social responsibility, resource-based theory, and sustainable competitive advantage. Journal of Management, 37: 1480-1495.

Miles, M. \& Huberman. A. 1994. Qualitative Data Analysis ( $2^{\text {nd }}$ edition). Thousand Oaks: Sage.

Mort, G., Weerawardena, J., \& Carnegie, K. 2003. Social entrepreneurship: Towards conceptualization. International Journal of Nonprofit and Voluntary Sector Marketing, 8 76-88.

Peredo, A.M. \& Chrisman, J. 2006. Towards a theory of community-based enterprise. Academy of Management Review, 31: 309-328.

Peredo, A.M. \& McLean, M. (2006). Social entrepreneurship: A critical review of the concept. Journal of World Business, 41 56-65.

Porter, M. 1980. Competitive Strategy. New York: Free Press.

Porter, M. 1985. Competitive Advantage. New York: Free Press.

Prahalad, C.K. 2004. The Fortune at the Bottom of the Pyramid: Eradicating Poverty through Profits. Upper Saddle River, NJ: Wharton School Publishing.

Purkayastha, D. 2009. Trevor Field and the PlayPumps of Africa. Case Studies in Social Entrepreneurship and Sustainability: The oikos Collection Vol 2 228-255.

Reinhardt, F. 1998. Environmental product differentiation: Implications for corporate strategy. California Management Review, 40: 43-73.

Richards, L. 2009. Handling Qualitative Data: A Practical Guide (2 ${ }^{\text {nd }}$ Edition). Thousand Oaks, CA: Sage.

Robinson, J. 2006. Understanding the strategy, structure and outcomes in social ventures. In J Mair, J Robinson, and K Hockerts (eds.) Social Entrepreneurship, New York: Palgrave 139-141.

Russo, M. 2010. Companies on a Mission: Entrepreneurial Strategies for Growing Sustainably, Responsibly, and Profitably. Stanford: Stanford University Press. 
Sarasvathy, S . 2008. Effectuation: Elements of Entrepreneurial Expertise. Cheltenham, UK: Edward Elgar.

Scherer, F. \& Ross, D. 1990. Industrial Market Structure and Economic Performance, $3^{\text {rd }}$ edition. Boston: Houghton Mifflin.

Shane, S. 2000. Prior knowledge and the discovery of entrepreneurial opportunities. Organization Science, 11: 448-469.

Shaw, E. \& Carter, S. 2007. Social entrepreneurship: Theoretical antecedents and empirical analysis of entrepreneurial processes and outcomes. Journal of Small Business and Enterprise Development, 14 418-434.

Short, J., Moss, T., \& Lumpkin, G. 2009. Research in social entrepreneurship: Past contributions and future opportunities. Strategic Entrepreneurship Journal, 3: 161-194.

Teece, D., Pisano, G. \& Shuen, A. 1997. Dynamic capabilities and strategic management. Strategic Management Journal, 18: 509-533.

Teece, D. (2007) Explicating dynamic capabilities: The nature and microfoundations of (sustainable) enterprise performance. Strategic Management Journal, 28: 1319-1350.

Tregidga, H., Kearins, K., \& Collins, E. 2009. Kapai New Zealand: Eat Your Greens! Case Studies in Social Entrepreneurship and Sustainability: The oikos collection Vol 2, 89-109.

Venkataraman, S. \& Sarasvathy, S. 2001. Strategy and entrepreneurship: Outlines of an untold story. In Hitt,M, Freeman RE and Harrison J (eds.) Handbook of Strategic Management. Oxford, Blackwell, 650668.

Wernerfelt, B. (1984) A resource based theory of the firm. Strategic Management Journal, 5:171-180.

Wheeler, D., McKague, K., Thomson, J., Davies, R. Medalye, J. \& Prada, M. 2005. Creating sustainable local enterprise networks. Sloan Management Review, 47:33-40.

Williams, R., Omar, M., \& Ensor, J. 2011. Sourcing or selling: The value flame at the base of the pyramid. Marketing Intelligence and Planning, 29: 233-246.

Yin, R. 2003. Case Study Research: Design and Methods (3 ${ }^{\text {rd }}$ edition). Thousand Oaks: Sage.

Yli-Renko, H., Autio, E., \& Sapienza, H. 2001. Social capital, knowledge acquisition, and knowledge exploitation in young, technology based firms. Strategic Management Journal, 22: 587-613.

Zahra, S., Gedajlovic, E., Neubaum, D., \& Shulman, J. 2009. A typology of social entrepreneurs: Motives, search processes, and ethical challenges. Journal of Business Venturing, 24: 519-532.

Zahra, S. \& Wright, M. 2011. Entrepreneurship's next Act. Academy of Management Perspectives, November: 67-83. 
Table 1

Well Known Strategy Frameworks

\begin{tabular}{|c|c|c|c|}
\hline Strategy Framework & Elements of Framework & Focus and Process & References \\
\hline $\begin{array}{l}\text { Industrial/ } \\
\text { Organizational } \\
\text { Economics (IOE) }\end{array}$ & $\begin{array}{l}\text { Competitive advantage (CA) gained } \\
\text { through... } \\
\text {-managing five industry forces } \\
\text { (buyers, suppliers, entry barriers, } \\
\text { substitutes, rivalry) } \\
\text {-creating unique position relative to } \\
\text { rivals within industry (differentiation, } \\
\text { low cost, focus) }\end{array}$ & $\begin{array}{ll}\text { Focus } & \\
& \text {-product-market focus } \\
& \text {-external, more on } \\
& \text { industry than firm } \\
\text { Process } & \\
& \text {-adjusting firm attributes } \\
& \text { to match external trends }\end{array}$ & $\begin{array}{l}\text { Porter, } 1980 \\
\text { Porter, } 1985\end{array}$ \\
\hline $\begin{array}{l}\text { Resource Based View } \\
\text { (RBV) }\end{array}$ & $\begin{array}{l}\text { CA gained through... } \\
\text {-capabilities of firms to acquire and } \\
\text { uniquely configure resources } \\
\text {-resource configurations that are } \\
\text { valuable, rare, inimitable, have no } \\
\text { substitutes }\end{array}$ & $\begin{array}{ll}\text { Focus } & \\
& \text {-resource focus } \\
& \text {-internal to firm, on } \\
& \text { firm's idiosyncratic } \\
& \text { resources } \\
\text { Process } & \\
& \text {-acquiring, configuring, } \\
& \text { and reconfiguring } \\
& \text { resources }\end{array}$ & $\begin{array}{l}\text { Wernerfelt,1984 } \\
\text { Barney, 1986 } \\
\text { Barney et al., } 2011 \\
\text { Teece et al., } 1997 \\
\text { Eisenhardt \& Martin, } 2000 \\
\text { Teece, 2007 } \\
\text { Helfat et al., } 2007\end{array}$ \\
\hline $\begin{array}{l}\text { Relational View } \\
\text { including stakeholder } \\
\text { perspective }(\mathrm{RV} / \mathrm{S})\end{array}$ & $\begin{array}{l}\text { CA gained through... } \\
\text {-difficult to imitate relationships } \\
\text { (dyads, networks) } \\
\text {-Dyadic/ network barriers to imitation } \\
\text { (inter-firm knowledge sharing } \\
\text { routines, complementary resource } \\
\text { endowments, asset stock } \\
\text { interconnectedness) } \\
\text {-instrumental stakeholder } \\
\text { relationships }\end{array}$ & $\begin{array}{ll}\text { Focus } & \\
& \text {-on relationships } \\
\text { Process } & \\
& \text {-regular patterns of } \\
& \text { interaction for dyad/ } \\
& \text { network }\end{array}$ & $\begin{array}{l}\text { Dyer and Singh, } 1998 \\
\text { Yli-Renko, Autio, \& Sapienza, } \\
2001 \\
\text { Zaheer et al. } 2010 \\
\text { Freeman, } 1984 \\
\text { McVea \& Freeman, } 2005\end{array}$ \\
\hline
\end{tabular}


Table 2

Case Descriptions

\begin{tabular}{|c|c|c|}
\hline \\
\hline Case & Service/ Product Provided & Social Value Created \\
\hline $\begin{array}{l}\text { PlayPumps } \\
\text { (Purkayastha, 2009) }\end{array}$ & $\begin{array}{l}\text {-Provides roundabouts (merry-go-rounds) that } \\
\text { pump water from boreholes while children play on } \\
\text { them and storage units for water that advertise } \\
\text { about important health issues (i.e., HIV in Africa) }\end{array}$ & $\begin{array}{l}\text {-Reduce death and illness due to lack of potable water } \\
\text {-improve gender equality by reducing amount of time women } \\
\text { devote to supplying families water } \\
\text {-Removes barrier to children attending school (less time spent } \\
\text { collecting water) } \\
\text {-Provides health education }\end{array}$ \\
\hline $\begin{array}{l}\text { ReUse People } \\
\text { (Corbett \& Powell, } \\
\text { 2009) }\end{array}$ & $\begin{array}{l}\text {-Provides deconstruction of residential and } \\
\text { commercial buildings in the US, storage for } \\
\text { reclaimed building materials, and retail sales of } \\
\text { reclaimed materials (i.e., hardwood floors) }\end{array}$ & $\begin{array}{l}\text {-Donates reclaimed items to economically disadvantaged Mexican } \\
\text { communities } \\
\text {-Offers job training for youth and promotion of volunteerism in the } \\
\text { California Conservation Corp }\end{array}$ \\
\hline $\begin{array}{l}\text { Kapai } \\
\text { (Tregidga, Kearins, } \\
\text { \& Collins, 2009) }\end{array}$ & $\begin{array}{l}\text {-Operates salad stores (restaurants) in New Zealand } \\
\text { selling menu items made of highest quality produce } \\
\text { (organic and locally sourced whenever possible) }\end{array}$ & $\begin{array}{l}\text {-Price menu items less than the minimum hourly wage rate for New } \\
\text { Zealand to ensure accessibility of wholesome food to all } \\
\text {-Promotes health and fitness of New Zealanders } \\
\text {-Returns a portion of net profit to local community projects }\end{array}$ \\
\hline $\begin{array}{l}\text { Wello } \\
\text { (Gordon, 2010) }\end{array}$ & $\begin{array}{l}\text {-Produces and distributes water wheels in Africa, } \\
\text { devices which enable collection and transport of } 4 \\
\text { times the amount of water collected by traditional } \\
\text { means and in much less time }\end{array}$ & $\begin{array}{l}\text {-Promotes gender equality because substantially reduces amount of } \\
\text { time (down from } 8 \text { hours/ day) that women and children must spend } \\
\text { collecting water for families } \\
\text { - Frees women to engage in income earning activities } \\
\text {-Frees children's time from water collection to attend school. }\end{array}$ \\
\hline $\begin{array}{l}\text { Trade Aid } \\
\text { (Ho \& Corner, } \\
2010 \text { ) }\end{array}$ & $\begin{array}{l}\text {-Imports hand-crafted and agricultural products } \\
\text { (coffee, tea, spices) from economically } \\
\text { disadvantaged groups into high retail value New } \\
\text { Zealand market }\end{array}$ & $\begin{array}{l}\text {-Generates income for economically disadvantaged groups } \\
\text {-promotes education of children (i.e., builds schools) for } \\
\text { economically disadvantaged groups } \\
\text {-Promotes gender equality, will only work with groups, NGOs } \\
\text { where women get an equal vote to men }\end{array}$ \\
\hline $\begin{array}{l}\text { WaterHealth } \\
\text { International(WHI) } \\
\text { (Faheem \& } \\
\text { Purkayastha, 2010) }\end{array}$ & $\begin{array}{l}\text {-Provides systems in economically disadvantaged } \\
\text { areas of India and Philippines that use ultraviolet } \\
\text { light technology (irradiation) to disinfect water } \\
\text { from harmful pathogens and microbes }\end{array}$ & $\begin{array}{l}\text {-Helps eliminate child disease associated with contaminated water } \\
\text { (e.g., diminutive growth, cholera) } \\
\text {-Promotes gender equality by freeing women and girls from } \\
\text { trekking long distances to collect water for families } \\
\text {-Allows women more time to engage in income generation for } \\
\text { family and girls to attend school }\end{array}$ \\
\hline
\end{tabular}


Table 3

Strategy Elements Present in SE

\begin{tabular}{|c|c|c|}
\hline Cases & $\begin{array}{l}\text { Strategy Elements } \\
\text { Present }\end{array}$ & Selected Examples \\
\hline PlayPumps & $\begin{array}{l}\text { IOE: } 5 \\
\text { RBV: } 4 \\
\text { RV/S: } 5\end{array}$ & $\begin{array}{l}\text { IOE: Registered "PlayPumps" as a trademark, a barrier to entry. } \\
\text { RBV: Developed multiple capabilities to enhance product performance including: power } \\
\text { generation, water storage, advertising, maintenance, user education. } \\
\text { RV/S: Cultivated relationships to gain necessary funding, including advertising relationships with } \\
\text { Colgate-Palmolive. }\end{array}$ \\
\hline The ReUse People & $\begin{array}{l}\text { IOE: } 5 \\
\text { RBV: } 2 \\
\text { RV/S: } 2\end{array}$ & $\begin{array}{l}\text { IOE: Built extended value chain emphasizing logistics and efficiency as a key to success. } \\
\text { RBV: Developed multiple capabilities including deconstruction of buildings, logistics, and } \\
\text { recycling, training, and education of prospective clients. } \\
\text { RV/S: Established an ongoing supply relationship with Home Depot, a large US chain of building } \\
\text { materials stores and the California Conservation Corps, an organization to train youth. }\end{array}$ \\
\hline Kapai & $\begin{array}{l}\text { IOE: } 7 \\
\text { RBV: } 2 \\
\text { RV/S: } 5\end{array}$ & $\begin{array}{l}\text { IOE: Differentiated products (salads) on criteria of un-processed, low-fat content, freshly made } \\
\text { from local produce, sold at an affordable price. } \\
\text { RBV: Demonstrated dynamic capabilities of creating, configuring, and reconfiguring scarce } \\
\text { resources as first store established, creating a model to possibly franchise. } \\
\text { RV/S: Developed relationship with small suppliers understanding that they might grow together. }\end{array}$ \\
\hline Wello & $\begin{array}{l}\text { IOE: } 6 \\
\text { RBV: } 4 \\
\text { RV/S: } 3\end{array}$ & $\begin{array}{l}\text { IOE: Created a value chain from where none of the activities were previously in place. } \\
\text { RBV: Designed and implemented a transportable manufacturing capability. } \\
\text { RV/S: Established relationships with social venture capital funds. }\end{array}$ \\
\hline Trade Aid & $\begin{array}{l}\text { IOE: } 9 \\
\text { RBV: } 6 \\
\text { RV/S: } 6\end{array}$ & $\begin{array}{l}\text { IOE: Certified agricultural products with fair trade trademark to differentiate from companies } \\
\text { using less rigorous fair trade standards, a barrier to entry. } \\
\text { RBV: Built capabilities including product development and education. } \\
\text { RV/S: Created inimitable relationships through long term commitments and good practice. }\end{array}$ \\
\hline $\begin{array}{l}\text { WaterHealth } \\
\text { International (WHI) }\end{array}$ & $\begin{array}{l}\text { IOE: } 15 \\
\text { RBV: } 5 \\
\text { RV/S: } 7\end{array}$ & $\begin{array}{l}\text { IOE: Changed offering from product to service given price/ margin calculations, and patented } \\
\text { technology to create an entry barrier. } \\
\text { RBV: Generated unique organizational structure to delivered extreme low cost service. } \\
\text { RV/S: Partnered with NGOs to educate clients on health benefits of pathogen-free water. }\end{array}$ \\
\hline
\end{tabular}


Table 4

SE Adaptations and Extensions of Well -Known Strategy Frameworks

\begin{tabular}{|c|c|c|}
\hline Framework & Adaptations and Extensions & Examples \\
\hline \multirow{2}{*}{ IOE } & $\begin{array}{l}\text { Five forces adapted } \\
\text {-entry barriers used } \\
\text {-Empowered buyers and } \\
\text { suppliers } \\
\text {-rivalry, "room for } \\
\text { competition" }\end{array}$ & $\begin{array}{l}\text {-PlayPumps, Trade Aid, and WHI used trademarks, patents as barriers to entry. } \\
\text {-Implicit ownership of Trade Aid by suppliers who received a share of the } \\
\text { company's profits, and collaborated in setting retail prices. } \\
\text {-PlayPumps empowered buyers by freeing up children for schooling and women to } \\
\text { earn income; also educated buyers about health issues. } \\
\text {-WHI and Kapai played leaders in their respective industries but both saw the social } \\
\text { need as large enough that rivals/competitors likely and somewhat welcome. }\end{array}$ \\
\hline & $\begin{array}{l}\text { Products/ Services with multiple } \\
\text { value points }\end{array}$ & $\begin{array}{l}\text {-Wello's water wheel had to create value beyond transporting water including: 1) } \\
\text { transporting substances other than water (i.e., gasoline, rice); and 2) functioning as } \\
\text { income generating device for prospective entrepreneurs wanting to transport } \\
\text { substances for fellow villagers. }\end{array}$ \\
\hline
\end{tabular}




\begin{tabular}{|c|c|c|}
\hline Framework & Adaptations and Extensions & Examples \\
\hline \multirow[t]{3}{*}{$\mathbf{R B V}$} & Unique funding abilities & $\begin{array}{l}\text {-WHI constructed a complex consortium of funders. } \\
\text {-Wello sourced funding from new breed of organization, social venture capital fund } \\
\text {-PlayPumps raised finance via the internet using social networks }\end{array}$ \\
\hline & $\begin{array}{l}\text { Complex structuring and } \\
\text { governance capabilities }\end{array}$ & $\begin{array}{l}\text {-Trade Aid, WHI, and PlayPumps have organizational structures that are a mix of } \\
\text { commercial and non-profit units. } \\
\text {-WHI created complex configuration of resources created to deliver the service of } \\
\text { potable water to customers. }\end{array}$ \\
\hline & $\begin{array}{l}\text { Capabilities reflect } \\
\text { entrepreneurs' life experience } \\
\text { and paradigm shifting } \\
\text { aspirations }\end{array}$ & $\begin{array}{l}\text {-Trade Aid infused with humanitarianism and identity of Vi Cottrell, founder. } \\
\text {-PlayPumps infused with drive and identity of Field. } \\
\text { - Founders of Kapai, PlayPumps, and Wello had paradigm-shifting aspirations, well } \\
\text { beyond the scale of what they alone could achieve. }\end{array}$ \\
\hline \multirow[t]{2}{*}{$\mathbf{R V} / \mathbf{S}$} & $\begin{array}{l}\text { Built ecosystems of relationships } \\
\text {-across multiple sectors } \\
\text {-included local groups to } \\
\text { build trust, and ensure } \\
\text { authenticity } \\
\text {-profits to partners, not } \\
\text { just focal firm }\end{array}$ & $\begin{array}{l}\text { - PlayPumps built innovative partnerships with individuals, governments, } \\
\text { foundations, and NGOs to donate PlayPumps to African communities. } \\
\text {-WHI launched the "blue revolution" in India (to provide water) with several private } \\
\text { companies, NGOs, and government organizations. } \\
\text {-PlayPumps worked with local governments and community leaders to set up their } \\
\text { merry-go-rounds and WHI established relationships with village elders in India to } \\
\text { secure resources for and commitment to water purifying systems. } \\
\text {-Trade Aid system of relationships included NGOs, agricultural cooperatives, family } \\
\text { groups and alternative trade organizations. } \\
\text {-Local community shared profits from WHI water systems when they invested. } \\
\text {-Trade Aid shared profits with suppliers of handcrafts and agricultural products. }\end{array}$ \\
\hline & $\begin{array}{l}\text { Created networks of } \\
\text { entrepreneurs/ (micro)franchise }\end{array}$ & $\begin{array}{l}\text {-Wello had "business in a barrel strategy"; idea was to empower end-users to use the } \\
\text { water wheel as an income-generating tool. } \\
\text {-WHI created entrepreneurs to distribute sanitized water through Aqua stores in the } \\
\text { Philippines, spawning entrepreneurial infrastructure in impoverished areas. }\end{array}$ \\
\hline
\end{tabular}

